\title{
The effect of ownership structure on leverage with credit rating as a moderating variable
}

\author{
Harjum Muharam ${ }^{1}$ and Galuh Kusuma Putri² \\ ${ }^{1,2}$ Department of Management, Faculty of Economics and Business, Universitas Diponegoro, Indonesia
}

Abstract
as a moderating variable. The ownership structure used in this study is government
ownership and managerial ownership. Leverage is measured using a debt to assets ratio
(DAR). Credit rating uses ratings issued by PEFINDO.The sample used in this study was
companies rated by PEFINDO and listed on the Indonesia Stock Exchange in $2015-2017$.
The number of samples used were 53 companies determined using a purposive sampling
method. The analysis using Ordinary Least Square (OLS) regression analysis indicated that
government ownership does not affect leverage, and the credit rating does not moderate
the relationship between government ownership and leverage. Managerial ownership has
a negative effect on leverage, and the credit rating moderates the relationship between
managerial ownership and leverage

\section{INTRODUCTION}

Leverage is the use of debt. Leverage is a tool used to find the proportion of a company's assets financed by debt and compared with equity (Weston \& Copeland, 1992). Financial leverage is caused by the manager's policy when determining the source of financing originating from outside the company, especially financing from debt. Ayyagari et al. (2010) stated that companies in China, funding sources of $20 \%$ came from banks and $80 \%$ came from other sources such as retained earnings, informal funding, family loans, trade credit, investment financing and equity. Chen (2004) suggests that determinants of leverage such as company size, profitability, growth opportunities and physical assets are also relevant in China.

Capital structure can be influenced by various factors, one of which is the type of ownership structure. Government ownership is often associated with high levels of leverage. This is because SOEs borrow more often than issuing shares (Dewenter \& Malatesta, 2001). SOEs also have loan guarantees that allow them to borrow at favorable prices. In companies in China, government ownership actually has a negative relationship to leverage. Companies with high government ownership tend to avoid financing from debt. Even if there is, the use of debt to companies with this type of ownership is not too strong (Chan et al., 2013).

When SOEs become controlling shareholders, they tend to explore the resources of their subsidiaries (Bradford et al., 2013). The controlling shareholders tend to support listed companies by providing credit guarantees and capital injections to maintain company funding and the feasibility of refinancing (Ying \& Wang, 2013). Meanwhile, when SOEs become the majority shareholders, they tend to use their subsidiaries to increase capital from the capital market which then makes the capital available for internal funding.

If government is not a major shareholder in a company, the government can't interfere too much with company affairs. This is because the proportion of shares owned is small, so it lacks the power to regulate the company. Sometimes the government itself deliberately reduces the proportion of its ownership so that they do not interfere too much and submit it to market mechanisms, especially to private-owned companies. In this study, non-government ownership will use the proportion of shares owned by the management of the company or more often called managerial ownership.

Corporate funding decisions are very dependent on the goals, desires, and perceptions of their managers (Zwiebel, 
1996). Managers focus on capital structures to ensure sufficient efficiency and prevent challenges to control. Managers limit the use of debt and are committed to improving operations to increase revenue (Leland \& Pyle, 1977). On the other hand, Berger \& Humphrey (1997) argue that managers will increase debt when managerial security is threatened by the possibility of failure in an accidental CEO bidding or replacement.

Another variable that is thought to also influence leverage is credit rating. Credit rating is an assessment of the credit risk of each individual, company and country. Credit rating can be calculated by looking at financial history, assets owned and liabilities. Credit rating gives an overview to creditors or investors to the level of possibility of the subject, whether it is individuals, companies or countries in paying their debts. Credit ratings measure credit worthiness and the ability to repay debts that affect the interest rate of the debt.

\section{LITERATURE REVIEW AND HYPOTHESES DEVELOPMENT}

\section{Government ownership}

Government ownership increases the cost of debt (Abramov et al., 2017). This is related to fulfilling the investment targets in the social and political aspects, so have an impact on the decline in the performance and value of the company. This causes a decrease in profitability and an increase in debt costs that are at high risk of default (Borisova et al., 2012). Companies with this type of ownership tend to have a high level of debt.

Companies operating in developing countries tend to have a greater degree of leverage than developed countries. This is because in developing countries, the management of the company has not been implemented optimally so that the company's performance is also not optimal

Huang et al., (2018) and Bhabra et al., (2008) suggest that government ownership has a positive effect on leverage. The role of the Chinese government in corporate funding decisions is very important, given its dual role as the largest shareholder of SOEs and owners of all major banks. The Chinese government tends to put pressure on banks to provide loans, especially to SOEs, this is what causes state-owned companies in China to have easy access to debt (Li et al.,
2009). Based on the description, the hypothesis can be formulated as follows:

H1: Government ownership has a positive effect on leverage

\section{Managerial ownership}

Companies with a majority of managerial ownership tend to optimize the use of income compared to using debt in financing their operations. The use of debt can reduce manager's freedom and high risk of default. If the debt experiences default, it will further increase the cost of bankruptcy. In the context of companies in Pakistan, company management will limit debt to reduce bankruptcy risks and costs (Hasan \& Butt, 2009). This is in line with the results of Brailsfordet al. (2002) who found that when managerial ownership is low it causes agency conflict rates to be low, which impacts on higher levels of debt. In addition, when companies use debt, supervision of the performance of managers in managing management will increase. This is in accordance with the opinion of Huang \& Song (2006) who stated that when managerial ownership increases, it will also increase behavior to anticipate risk, which leads to a decrease in the level of debt. Another supporting literature is research conducted by Wahba (2014) who argues that managerial ownership is negatively related to the capital structure of companies registered in Egypt. Based on the description mentioned, the hypothesis can be formulated as follows:

H2: Managerial ownership has a negative effect on leverage

\section{Credit rating on government ownership and leverage}

Companies with a majority of shares owned by the government have great access to external funding (Huang et al., 2016). The government as the majority shareholder has an important role in making funding decisions and has great access to getting loans, especially from banks. In addition, the government's good reputation in the market can also be taken into consideration for investors to invest in a company. In addition to the company's reputation, another thing that is considered by creditors is the protection of their rights. The better the 
protection of creditors, the more likely it is to increase public debt (Gu et al., 2018)

One company's reputation can be assessed from its credit rating. Credit rating is a rating that shows the company's ability to fulfill its obligations. Credit ratings can influence corporate funding decisions, this is consistent with the results of research by Krichene \& Khoufi (2016). Companies with high ratings can mean that the company is more financially stable so that it has the ability to pay its obligations. From this explanation it can be concluded that the credit rating also affects the company's leverage decisions, so the hypothesis can be formulated as follows:

\section{H3: Credit rating moderates the relationship between government ownership and leverage}

\section{Credit rating on managerial ownership and leverage}

Managers in companies with high levels of debt will be at higher risk than owners (Vo \& Nguyen, 2014). This is because if the debt level is high, managers are considered to be unable to manage the company's management optimally, increasing the likelihood of managers losing their jobs. This causes the manager to limit the use of debt to the company, thus minimizing the risks it faces. High managerial ownership also plays a role in balancing the interests of corporate management with shareholders which leads to a reduction in debt costs (Sun et al., 2015).

One of the factors that influence funding decisions is credit rating. Changes in credit rating will influence funding decision making (Krichene \& Khoufi, 2016). The change in credit rating has a significant effect on leverage the following year. Companies whose ratings go down will reduce debt the following year to regain investment levels. Based on the description, the hypothesis can be written as follows:

$$
\begin{aligned}
& \text { H4: Credit rating moderates the } \\
& \text { relationship between managerial } \\
& \text { ownership and leverage }
\end{aligned}
$$

\section{METHODS}

\section{Variables}

The dependent variable is a variable that is influenced by other variables. The dependent variable in this study is company leverage as measured by Debt to Assets Ratio (DAR). Debt to Assets Ratio is a ratio that shows how much the company's assets are financed by debt.

$$
D A R=\frac{\text { Total Debt }}{\text { Total Assets }}
$$

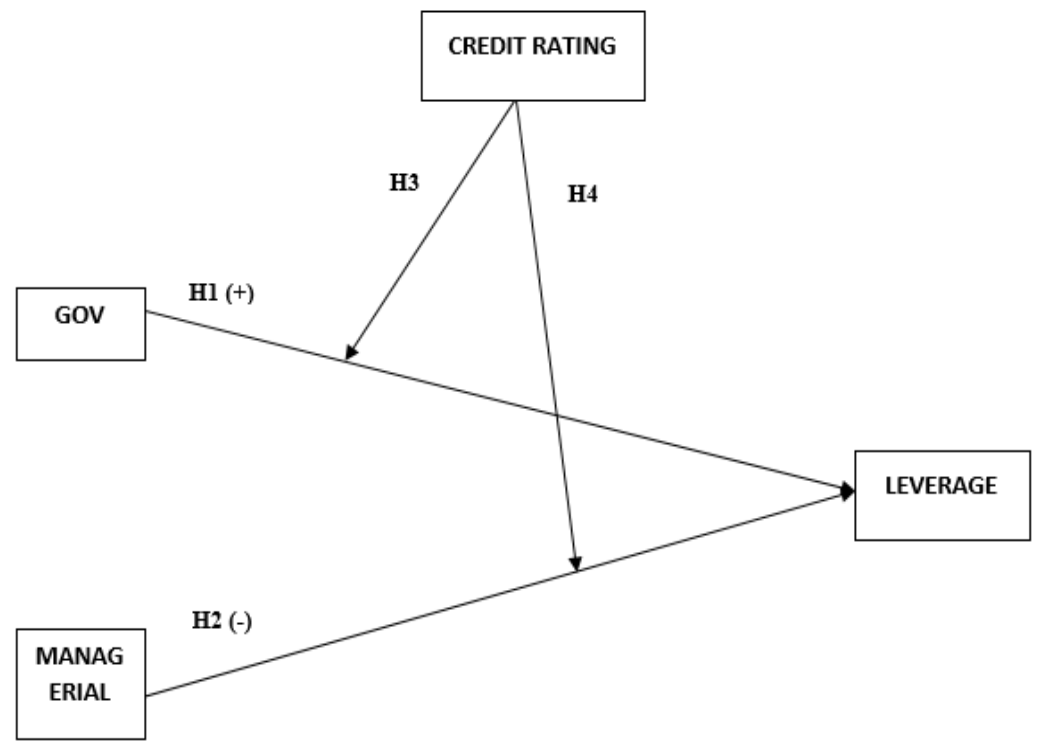

Figure 1.

Model Test 
Independent variables are variables that can affect other variables. Independent variables used in this study is government and managerial ownership. Government ownership is measured by the standardization value of the percentage of share ownership held by the government in the company, which can be seen from the annual report of each company. Managerial ownership is measured by the standardized value of the percentage of share ownership held by the company management, which can be seen from the annual report of each company.

$$
\begin{gathered}
Z G O V=\{(G O V-\overline{G O V}) / \sigma G O V\} \\
Z M A N=\{(M A N-\overline{M A N}) / \sigma M A N\}
\end{gathered}
$$

The moderating variable is a variable that strengthens or weakens the relationship between the independent variables on the dependent variable. The moderating variable used in this study is credit rating. Credit rating is an assessment of a company's ability to fulfill its obligations. To use credit rating as moderation, researchers use an ordinal scale to represent the rating at each level. For the idAAA rating is given a value of 7 , and the lower the value the smaller it becomes until the idCCC is given a value of 1 , then the rating value is standardized. In this study using a credit rating issued by PEFINDO.

This research used a multiple regression analysis test with the assumption of ordinary least square (OLS) and test of absolute difference value method.

Table 1.

Ordinal Scale for Rating Levels

\begin{tabular}{lc}
\hline Rating & Ordinal Scale \\
\hline idAAA & 7 \\
idAA & 6 \\
idA & 5 \\
idBBB & 4 \\
idBB & 3 \\
idB & 2 \\
idCCC & 1 \\
\hline \\
$Z C R=\{(C R-\overline{C R}) / \sigma C R\}$
\end{tabular}

\section{Population and sampling}

The population in this study was a company rated by PEFINDO and listed on the Indonesia Stock Exchange (IDX) for the period 2015 - 2017. The sample used was a company that was rated by PEFINDO during the 2015 to 2017 period and issued an annual report.

\section{Results and Discussion}

Descriptive statistics of leverage variable have a minimum value of $0.222 \mathrm{X}$ which is owned by Bumi Serpong Damai Tbk. (BSDE) in 2016, while the maximum value of $0.940 \mathrm{X}$ is owned by Apexindo Pratama Duta Tbk. (APEX) in 2016. For the variable average (mean) the leverage is $0.569 \mathrm{X}$ and the standard deviation is $0.157 \mathrm{X}$.

\section{Descriptive statistics}

Descriptive statistics of government ownership variable show that the minimum value of $-0.564 \mathrm{X}$ is owned by companies that do not have a percentage of government ownership. The following company codes that do not have a government ownership percentage include: JPFA, GJTL SMSM, TAXI, WEHA, AKRA, LTLS, WTON, ICBP, MYOR, ROTI, STTP, AISA, GDST, BMTR, ANTM (2017), TINS (2017), MEDC, APEX, RUIS, BWPT, SIMP, APLN, ELTY, BSDE, DART, DILD, MDLN, PPRO (2015), SMRA (2016 and 2017), SSIA, FAST, MPPA, TELE, MYRX, FISH, INTA, TGKA and PANPR. Meanwhile, the maximum value is 2,611X owned by Kimia Farma (Persero) Tbk. in 2015-2017. For the mean value of $0.0197 X$ and the standard deviation of $0.978 X$.

Descriptive statistics of managerial ownership variables show that the minimum value of $-0.403 \mathrm{X}$ is owned by companies that do not have a percentage of managerial ownership. The following code of companies that do not have managerial ownership include: JPFA, TAXI, WEHA (2016 and 2017), AKRA (2015 and 2017), LTLS (2016), ADHI, WSKT (2015 and 2016), WIKA, WTON, ICBP, MYOR (2015), ROTI, AISA, ANTM, TINS, MEDC, PGAS, APEX, RUIS, INAF, BWPT, SIMP, ELTY, BSDE, DART 
Table 2.

Descriptive Statistics

\begin{tabular}{llllll}
\hline & $\mathrm{N}$ & Minimum & Maximum & Mean & Std. Deviation \\
\hline LEVERAGE & 150 & 0,222 & 0,940 & 0,56942 & 0,157442 \\
GOV & 150 & $-0,564$ & 2,611 & $-0,01977$ & 0,978236 \\
MAN & 150 & $-0,403$ & 5,332 & 0,02419 & 1,024693 \\
CR & 150 & $-2,500$ & 1,759 & 0,06954 & 0,943529 \\
SQRTSNM1 & 150 & 0,38 & 2,02 & 0,9555 & 0,39427 \\
SQRTSNM2 & 150 & 0,16 & 2,39 & 0,8979 & 0,45279 \\
Valid N (listwise) & & & & & \\
\hline
\end{tabular}

Note. Sourced from output SPSS, 2019.

(2015), DILD (2015 and 2016), PPRO, PJAA, FAST, MPPA, ISAT, TELE, SSMR (2017), FISH, ITA (2016 and 2017), TGKA, PANPR (2015 and 2016). Meanwhile, the maximum value of $5.332 \mathrm{X}$ is owned by Gunawan Dianjaya Steel Tbk. in 2015. For the mean value of $0.242 X$ and the standard deviation of $1.025 \mathrm{X}$.

Descriptive statistics for credit rating variables show that the minimum value of $2,500 \mathrm{X}$ is owned by companies with an idCCC rating, namely Bakrieland Development Tbk. in 2015-2017. Meanwhile, the maximum value for the credit rating variable which is equal to $1.759 \mathrm{X}$ is owned by a company with an idAAA rating. The following codes of companies with an idAAA rating include: APEX (2015 and 2016), SMRA (2017), ISAT, TLKM, and JSMR (2015 and 2016). For the average value (mean) that is equal to $0.695 \mathrm{X}$ and the standard deviation is $0.944 \mathrm{X}$.

Descriptive statistics of the interaction variable between government ownership and credit rating show that the minimum value of $0.38 \mathrm{X}$ is owned by Jasa Marga (JSMR) in 2015 and 2016, while the maximum value of $2.02 \mathrm{X}$ is owned by Indofarma Tbk. (INAF) in 2015 and 2016. For the average value of this variable is $0.9555 \mathrm{X}$ and the standard deviation is $0.394 X$

Descriptive statistics of the interaction variable between managerial ownership and credit rating show that the minimum value of $0.16 \mathrm{X}$ is owned by Mayora Indah Tbk. (MYOR) in 2016 and 2017. Meanwhile, the maximum value of $2.39 \mathrm{X}$ is owned by Gunawan Dianjaya Steel Tbk. (GDST) in 2015. For the mean value of this variable is $0.8979 \mathrm{X}$ and the standard deviation is $0.45279 X$.

\section{Determination coefficient test ( $R 2$ )}

Table 3 shows that the coefficient of determination (adjusted R2) in model 1 of the independent variable can affect the dependent variable by $34 \%$, while $66 \%$ of leverage is influenced by other variables outside the research model. In model 2 the independent variable can affect $7,1 \%$, while $92,9 \%$ of leverage is influenced by other variables.

\section{Simultaneous significance test (F-Test)}

In Table 4 presents significance values for each regression model of 0,000 and 0,005. From these results, it can be concluded that all variables of the two regression models jointly influence the dependent variable namely leverage.

The test results for the first hypothesis show that government ownership has no effect on leverage. In the study of Huang et al. (2018) stated that government ownership has no influence on leverage, when the government is not the majority shareholder. The value of the probability of government ownership that is not significant shows that government ownership is a less meaningful explanation for leverage. This is because the number of research samples that have little government ownership cannot significantly influence leverage. Based on the description above, it is concluded that the first hypothesis is rejected.

The results of testing the second hypothesis show that managerial ownership negatively affects leverage, according to the results of Vo \& Nguyen (2014). The negative influence between managerial ownership and leverage shows the opposite relationship Huang \& Song (2006) state that when managerial ownership increases, it will also increase behaviors to anticipate risk, 
leading to a decrease in debt. Significant managerial ownership values indicate that managerial ownership is an explanatory meaning for leverage. Based on the description above, it is concluded that the second hypothesis is accepted.

The results of testing the third hypothesis show that the credit rating does not moderate the relationship between government ownership of leverage. The results of these tests contradict the results of research by Krichene \& Khoufi (2016). The negative coefficient between the interaction variables of government ownership and the credit rating on leverage shows a relationship that weakens the relationship between government ownership of leverage. The probability value of the SQRTSNM1 variable that is not significant shows that the interaction variables of government ownership and credit rating are explanatory which are less meaningful for leverage. So, it can be concluded that the credit rating variable does not moderate the relationship between government ownership of leverage, so the third hypothesis is rejected.

The results of testing the fourth hypothesis show that the credit rating moderates the relationship between managerial ownership of leverage, this is in accordance with the results of research by Sun et al., (2015). The positive coefficient between the SQRTSNM2 variable on leverage shows a relationship that strengthens the relationship between managerial ownership of leverage. The significant probability value of the SQRTSNM2 variable indicates that the managerial ownership interaction variable and credit rating are explanatory meaning for leverage. Based on the description

Table 3.

Determination Coefficient Test

\begin{tabular}{ccrrr}
\hline Regression Model & R & R Square & $\begin{array}{c}\text { Adjusted R } \\
\text { Square }\end{array}$ & Std. Error of the Estimate \\
\hline Model 1 & 0,595 & 0,354 & 0,340 & 0,127868 \\
Model 2 & 0,309 & 0,096 & 0,071 & 0,151765 \\
\hline
\end{tabular}

Note. Sourced from output SPSS, 2019.

Table 4.

F-Statistic Test

\begin{tabular}{ccc}
\hline Regression Model & F & Sig. \\
\hline Model 1 & 26,631 & 0,000 \\
Model 2 & 3,839 & 0,005 \\
\hline
\end{tabular}

Note. Sourced from output SPSS, 2019.

Table 5.

Hypotheses Test

\begin{tabular}{|c|c|c|c|c|c|c|}
\hline \multicolumn{7}{|c|}{ Coefficients $^{a}$} \\
\hline & \multirow[b]{2}{*}{ Model } & \multicolumn{2}{|c|}{$\begin{array}{l}\text { Unstandardized } \\
\text { Coefficients }\end{array}$} & \multirow{2}{*}{$\begin{array}{c}\begin{array}{c}\text { Standardized } \\
\text { Coefficients }\end{array} \\
\text { Beta } \\
\end{array}$} & \multirow[b]{2}{*}{ t } & \multirow[b]{2}{*}{ Sig. } \\
\hline & & B & Std. Error & & & \\
\hline \multirow[t]{4}{*}{1} & (Constant) & ,564 & ,010 & & 53,872 &, 000 \\
\hline & GOV & ,009 & 011 & 057 & ,849 & ,397 \\
\hline & MAN &,- 038 & ,010 &,- 250 & $-3,755$ &, 000 \\
\hline & CR & 0,91 & 011 &, 545 & 8,181 &, 000 \\
\hline \multirow[t]{5}{*}{2} & (Constant) & ,528 & ,038 & & 13,755 &, 000 \\
\hline & GOV & ,016 & 015 & ,098 & 1,074 & ,285 \\
\hline & MAN &,- 056 & 015 &,- 367 & $-3,657$ &, 000 \\
\hline & SQRTSNM1 &,- 038 & ,042 &,- 095 &,- 901 & ,369 \\
\hline & SQRTSNM2 & .089 & 036 & 255 & 2,439 & 016 \\
\hline
\end{tabular}

a. Dependent Variable: Firm Performance

b. Significant in $5 \%$ 
above, it is concluded that the fourth hypothesis is accepted.

\section{CONCLUSION}

Ownership structure can affect leverage. In the first hypothesis the variables of government ownership are used as independent variables. From the test results it was found that government ownership did not affect leverage. This is because the amount of government ownership in the data that is examined is too little so that it does not have a significant effect on leverage. Managerial ownership variables are used as independent variables. From the test results it was found that managerial ownership negatively affected leverage.

Another factor that can affect leverage is credit rating. In the third hypothesis the credit rating does not moderate the relationship between government ownership of leverage. However, in the fourth hypothesis the credit rating moderates the relationship between managerial ownership of leverage.

Our research has limitations. The sample used is limited because the number of companies listed on the Indonesia Stock Exchange and rated by PEFINDO for the period 2015 to 2017 is only 53 companies.

With the limitations above, improvements are needed for future research. Therefore, suggestions that can be given are data need to be adjusted and manipulated before testing and testing can be equipped with other methods, so that the most appropriate method is obtained.

\section{REFERENCES}

Abramov, A., Radygin, A., Entov, R., \& Chernova, M. (2017). State ownership and efficiency characteristics. Russian Journal of Economics, 3(2), 129-157.

Ayyagari, M., Demirgüç-Kunt, A., \& Maksimovic, V. (2010). Formal versus informal finance: Evidence from China. The Review of Financial Studies, 23(8), 3048-3097.

Berger, A. N., \& Humphrey, D. B. (1997). Efficiency of Financial Institutions: International Survey and Directions for Future Research. European Journal of Operational Research.

Bhabra, H. S., Liu, T., \& Tirtiroglu, D. (2008). Capital Structure Choice in a Nascent Market: Evidence from Listed Firms in
China. Financial Management, 37(2), 341-364.

Borisova, G., Fotak, V., Holland, K., \& Megginson, W. L. (2012). Government Ownership and the Cost of Debt: Evidence from Government Investments in Publicly Traded Firms.

Bradford, W., Chen, C., \& Zhu, S. (2013). Cash Dividend Policy , Corporate Pyramids, and Ownership Structure: Evidence from China. International Review of Economics and Finance, 27, 445-464.

Brailsford, T. J., Oliver, B. R., \& Pua, S. L. H. (2002). On the relation between ownership structure and capital structure. Accounting and Finance.

Chan, K. H., Mo, P. L. L., \& Zhou, A. Y. (2013). Government Ownership, Corporate Governance and Tax Aggresiveness: evidence from China. Accounting and Finance, 53(4), 1029-1051.

Chen, J. J. (2004). Determinants of capital structure of Chinese-listed companies. Journal of Bussiness Research, 13411351.

Dewenter, K. L., \& Malatesta, P. H. (2001). StateOwned and Privately Owned Firms: An Empirical Analysis of Profitability , Leverage, and Labor Intensity. The American Economic Review, 91(1), 320-334.

Gu, X., Kadiyala, P., \& Mahaney-Walter, X. W. (2018). How creditor rights affect the issuance of public debt: The role of credit ratings. Journal of Financial Stability, 39, 133-143.

Hasan, A., \& Butt, S. A. (2009). Impact of Ownership Structure and Corporate Governance on Capital Structure of Pakistani Listed Companies. International Journal of Business and Management, 4(2), 50-57.

Huang, G., \& Song, F. M. (2006). The determinants of capital structure: Evidence from China. China Economic Review, 17(1), 14-36.

Huang, X., Kabir, R., \& Zhang, L. (2016). Government ownership, Concentration, and the Capital Struture of firms: Emprical Analysis of an Institutional Context from China.

Huang, X., Kabir, R., \& Zhang, L. (2018). Government ownership and the capital structure of firms: Analysis of an institutional context from China. China Journal of Accounting Research, 11(3), 171-185. 
Krichene, A. F., \& Khoufi, W. (2016). The effects of credit rating grades ' changes on capital structure: S \& $\mathrm{P}$ 500. The International Journal of Engineering and Science, 5(2), 48-57.

Leland, H. E., \& Pyle, D. H. (1977). Informational Asymmetries, Financial Structure, and Financial Intermediation. The Journal of Finance, 32(2), 371-387.

Li, K., Yue, H., \& Zhao, L. (2009). Ownership, Institutions, and Capital Structure: Evidence from China. Journal of Comparative Economics, 37(3), 471490.

Sun, J., Ding, L., Guo, J. M., \& Li, Y. (2015). Ownership, capital structure and financing decision: Evidence from the UK. British Accounting Review, 48(4), 448-463.

Vo, D. H., \& Nguyen, V. T.-Y. (2014). Managerial Ownership, Leverage and Dividend Policies: Empirical Evidence from Vietnam's Listed Firms. International Journal of Economics and Finance, 6(5), 274-284.

Wahba, H. (2014). Capital Structure, managerial ownership and firm perfomamnce: evidence from Egypt. Journal of Management and Governance, 18(4), 817-838.

Weston, J. F., \& Copeland, T. E. (1992). Manajemen Keuangan.

Ying, Q., \& Wang, L. (2013). Propping by controlling shareholders, wealth transfer and firm performance: Evidence from Chinese listed companies. China Journal of Accounting Research, 6(2), 133-147.

Zwiebel, J. (1996). Dynamic Capital Structure under Managerial Entrenchment. The American Economic Review, 86(5), 1197-1215. 